\title{
JOURNAL.RU
}

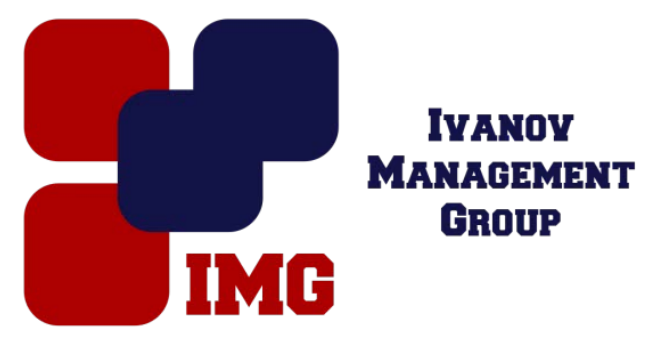

Токарева К.Г., Садыкова М.Г. Набережночелнинский филиал ЧОУ ВО «Казанский инноващионный университет им. В.Г. Тимирясова (ИЭУП)》 Набережные Челны, Россия

doi: 10.18411/lj-30-11-2016-3-13

idsp 000001:lj-30-11-2016-3-13

\section{Существенное нарушение договора пожизненного содержания с иждивением}

\section{Аннотация}

Статья посвящена рассмотрению существенного нарушения договора пожизненного содержания с иждивением как одному из специальных оснований прекращения данного договора. Автор, учитывая теоретические и практические аспекты, анализирует данный вопрос и дает практические рекомендации.

Ключевые слова: договор пожизненного содержания с иждивением, существенное нарушение договора, лишение жизни получателя ренты

В ст. 605 Гражданского кодекса Российской Федерации (далее - ГК РФ) предусмотрены основания и последствия прекращения договора пожизненного содержания с иждивением. В определенной части они совпадают с теми, которые установлены и для договора пожизненной ренты. В частности, оба договора предполагают, что отношения между сторонами прекращаются со смертью получателя ренты. Кроме того, в обоих случаях договор может быть прекращен по требованию получателя ренты в связи с существенным нарушением плательщиком его обязанностей. В таких случаях по договору пожизненного содержания с иждивением получатель ренты вправе потребовать либо выплаты выкупной цены, либо возврата переданного в обеспечение ренты недвижимого имущества. И если он остановился на втором варианте, независимо от того, передано ли имущество плательщику за плату или безвозмездно, - возврату подлежит все имущество без зачета уже произведенных расходов, связанных с содержанием получателя ренты. При оценке допущенного нарушения с точки зрения отнесения его к числу существенных следует, очевидно, исходить из того определения, которое содержится в п. 2 ст. 450 ГК РФ. Указанная норма признает существенным нарушение договора одной из сторон, которое влечет для контрагента такой 
ущерб, что он в значительной степени лишается того, на что был вправе рассчитывать при заключении договора.

В судебной практике по делам данной категории часто встает вопрос о том, что считать существенным нарушением договора. Прекращение обязательства пожизненного содержания с иждивением по данному основанию имеет две особенности по сравнению с аналогичным прекращением обязательства пожизненной ренты. Во-первых, более широким является перечень тех нарушений обязательств плательщика ренты, которые должны считаться существенными. К ним дополнительно относятся отчуждение, сдача в залог или иное обременение имущества, переданного в обеспечение пожизненного содержания, без предварительного согласия получателя ренты, а также утрата, повреждение имущества или иные действия (бездействие) плательщика ренты, которые приводят к существенному снижению стоимости этого имущества. Во-вторых, при существенном нарушении плательщиком ренты своих обязательств получатель ренты вправе потребовать либо возврата недвижимого имущества, переданного в обеспечение пожизненного содержания, либо выплаты ему выкупной цены ренты. Если плательщик ренты произвел отчуждение имущества, то при решении вопроса, может ли оно быть истребовано получателем ренты у третьего лица, учитываются правила ст. 302 ГК РФ. По смыслу закона, если имущество было передано за плату, последняя должна быть возвращена плательщику ренты с учетом износа имущества, т. е. соответственно уменьшена. Но специально подчеркивается, что плательщик ренты не вправе требовать компенсации расходов, понесенных в связи с содержанием получателя ренты (п. 2 ст. 605 ГК РФ).

Приведем пример из судебной практики.

Согласно Решения Советского районного суда г. Казани от 16 мая 2016 г. Дело № 2-6130/2016 «О расторжении договора пожизненного содержания с иждивением»Каримуллина С.А. (далее также истец) обратилась в суд с иском к Каримуллиной Е.Г. (далее также ответчик) о расторжении договора пожизненного содержания с иждивением, заключенного между Каримуллина С.А. и Каримуллиной Е.Г.В обоснование заявленных требований указано, что между сторонами был заключен договор пожизненного содержания с иждивением в соответствии с которым истец передала бесплатно в собственность ответчику, принадлежащую ей на праве собственности квартиру, а ответчик обязался пожизненно полностью содержать истца, обеспечивая его питанием, одеждой, уходом и необходимой помощью, в том числе медицинской (вызов врача, скорой медицинской помощи, других специалистов лечебных учреждений, приобретение лекарств и медицинских препаратов), сохранив за ним право пожизненного бесплатного пользования и проживания в указанной квартире. Вместе с тем, ответчик, с момента заключения договорапо настоящее время принятые на себя обязательства по договору не исполняет, ежемесячных денег на содержание, питание, уход и лечение не предоставляет, оплату за квартиру, коммунальные услуги, услуги связи и другие услуги не производит, не 
обеспечивает питанием, одеждой, должным уходом, необходимой помощью. Таким образом, учитывая, что главной целью заключения договора пожизненного содержания с иждивением является получение материального содержания, ухода, обеспечение питанием, одеждой, лекарственными средствами со стороны плательщика ренты, неисполнение ответчиком договора в этой части в значительной степени лишает истца того, на что он был вправе рассчитывать при заключении договора, в связи с чем, истец считает, что плательщиком ренты были существенно нарушены условия спорного договора.

Данный иск был судом удовлетворен.

Интересны примеры судебной практики, когда получатель ренты обращается в суд с иском о расторжении договора.

Например, вот случай из практики Верховного суда (дело Рихтер М.Н. против Долгополовой О.В.). В июне 2006 г. Рихтер М.Н. обратилась в Преображенский межмуниципальный суд Москвы с иском к Долгополовой О.В. о признании договора недействительным, ссылаясь на то, что ко времени заключения договора находилась в тяжелом болезненном состоянии. В апреле 2007 г. она изменила предмет иска и просила расторгнуть вышеназванный договор, указав, что ответчик взятые на себя по договору обязательства по ее содержанию и уходу не выполняет.

11 июля 2007 г. Рихтер М.Н. умерла. Решением Преображенского межмуниципального суда Москвы от 27 января 2009 г., оставленным без изменения определением судебной коллегии по гражданским делам Московского городского суда от 8 апреля 2009 г., договор купли-продажи квартиры с пожизненным содержанием, заключенный 29 января 2006 г. между Рихтер М.Н. и Долгополовой О.В., расторгнут. Решение суда обжаловалось в кассационном и надзорном порядке, но безрезультатно. Президиум Верховного суда РФ, рассмотрев протест заместителя генерального прокурора РФ, не нашел оснований для его удовлетворения. Верховный суд указал, что, хотя в соответствии с ч. 1 ст. 605 ГК РФ обязательство пожизненного содержания с иждивением прекращается смертью получателя ренты, право требовать возврата имущества в связи с расторжением договора из-за существенного нарушения его условий плательщиком ренты (ч. 2 ст. 605 ГК РФ) переходит к наследникам.

Из приведенного примера следует сделать вывод, что иск о расторжении договора пожизненной ренты или пожизненного содержания с иждивением может быть предъявлен лишь самим получателем ренты при жизни. Наследники плательщика ренты после смерти последнего могут выступать лишь как правопреемники и самостоятельного иска не имеют.

Проблематичным является вопрос о последствиях умышленного лишения жизни получателя ренты плательщиком ренты. В данном случае наследники погибшего от руки плательщика ренты рентополучателя вправе ставить вопрос о применении аналогии права, когда при невозможности использования аналогии закона права и обязанности сторон определяются исходя из общих начал и смысла гражданского законодательства (аналогии права) и требований 
добросовестности, разумности и справедливости. Однако истребование имущества, полученного по договору ренты или пожизненного содержания с иждивением, возможна лишь после вступления в силу обвинительного приговора суда в отношении плательщика ренты. 


\section{Литература}

1. Брагинский М.И., Витрянский В. В. Договорное право. Договоры о передаче имущества. Книга 2. - М.: Статут, 2011.

2. Токарева К.Г. Совпадение должника и кредитора в одном лице как основание прекращения договора пожизненного содержания с иждивением // Нотариус. - 2014. - № 8. - С. 30-32.

3. Токарева К.Г. Общие основания прекращения обязательств по выплате ренты // Юрист. - 2009. - №5. - С.42-45.

4. Решение Советского районного суда г. Казани от 16 мая 22016 г. Дело № 2-6130/2016 «O расторжении договора пожизненного содержания с иждивением» // Режим доступа: https://rospravosudie.com/court-sovetskijrajonnyj-sud-g-kazani-respublika-tatarstan-s/act-524748871/

5. Постановление Президиума Верховного Суда РФ от 10 января 2011 года «Исковые требования о расторжении договора купли-продажи квартиры с условием пожизненного содержания удовлетворены правомерно, так как предметом спора являлось требование получателя ренты о возврате квартиры ввиду существенного нарушения плательщиком ренты своих обязательств и в правоотношении по возврату квартиры правопреемство являлось допустимым» // Бюллетень Верховного Суда РФ. - 2011. - № 7. C. 11-12. 